UDC: 631.417 .2

\title{
LONG-TERM DYNAMICS OF HUMUS CONTENT UNDER DIFFERENT TECHNOLOGIES OF SOIL TILLAGE
}

\author{
O. V. Demydenko ${ }^{1}$, P. I. Boyko ${ }^{2}$, V. A. Velychko ${ }^{3}$ \\ ${ }^{1}$ Cherkasy State Agricultural Experimental Station, NSC “Institute of Agriculture”, NAAS of Ukraine \\ 13, Dokuchaiev Str., Kholodnianske village, Smila District, Cherkasy Region, Ukraine, 20731; \\ e-mail:smilachiapv@ukr.net \\ ${ }^{2}$ NSC "Institute of Agriculture” NAAS \\ 2-b, Mashynobudivnykiv Str., Chabany village, Kyiv-Sviatoshyn District, Kyiv Region \\ e-mail:iznaan@ukr.net \\ ${ }^{3}$ NSC Institute for Soil Science and Agrochemistry Research named after O. Sokolovsky \\ 4, Chaikovskoho Str., Kharkiv, Ukraine 61024; \\ e-mail: agrovisnyk@ukr.net
}

Received on February 02, 2018

\begin{abstract}
The continuous agronomic experiment revealed long-term dynamics of the total humus content and presented a forecast of the change in humus content in typical low humus chernozem under different technologies of tillage till 2050. Aim. To determine the rates of humus accumulation dynamics and mineralization of total humus and to develop the forecast of the change in its content within a continuous agronomic experiment under longstanding application of different technologies of soil tillage to typical low humus chernozem of the Left-Bank Forest-Steppe of Ukraine. Methods. Field, laboratory-analytical, mathematical and statistical. Results. The application of different technologies of tillage to typical low humus chernozem for 42 years resulted only in the delay in dehumification processes and some stabilization of humus mineralization, but it did not promote its preservation and extended restoration to the initial level as of the start of the experiment. The increase in the total humus content for simple and extended restoration of humus in the centennial cycle equaled 20-25 $\mathrm{t}$ and 30-33 $\mathrm{t}$ per 1 ha respectively. To ensure the increase in content and reserves of humus for 42 years, it is necessary to introduce 10-12 t of humus per 1 ha for simple restoration of total humus content and 14-15 t per 1 ha - for extended restoration annually. Conclusions. Simple restoration of humus in typical chernozem may be stated after achieving its actual (2017) content of at least $90 \%$ from the content as of the beginning of the centennial cycle (92 years), which ensures maximal approximation to the non-decreasing cycle of humus dynamics trends in the centennial cycle. If the humus content is ensured in the actual measurement for the level, exceeding $90 \%$ from the initial content, and dynamics trends are growing, one may state the success of achieving the state of extended restoration of humus. The obtained state of simple and extended accumulation of humus is ensured by the positivity of the trends of humus increase during the continuous experiment (42 years) with simultaneous decrease in dehumification process in the centennial cycle (92 years) which is impossible to neutralize completely.
\end{abstract}

Keywords: typical chernozem, organic matter, humus, trend, straw, manure, mineral fertilizers, humification, soil tillage.

DOI: 10.15407 /agrisp5.01.003

\section{INTRODUCTION}

Humus content is the most important index of fertility and agroecological state of chernozems. The orga-

(C) O. V. DEMYDENKO, P. I. BOYKO, V. A. VELYCHKO, 2018 nic matter defines its structural-aggregate condition, its physical, chemical, and exchange properties, and is a considerable source of nutrients [1-8]. Humus ensures the resistance of chernozem to external impact, thus promoting one of the overall functions - its biogenicity [9-13]. Due to intense processes of humus mineraliza- 


\section{DEMYDENKO et al.}

tion under the impact of anthropogenic burden, chernozem acquires the features of agrophysical degradation [14]. Numerous studies demonstrate active manifestation of dehumification during the tillage of chernozems and their further usage in agriculture [15]. The application of fertilizers and different systems of tillage and crop rotations is a powerful factor, impacting the parameters of the humus state of chernozems and the implementation of their potential fertility via its effective form $[15,16]$. However, the fertilizers satisfy the needs related to the decrease in humus reserves [13] and humus balance in chernozems while cultivating some crops only by $50-60 \%$.

Modern studies of humus content dynamics are related to solving rather complicated methodological problems [17], caused, first of all, by the spectrum of chernozem humus, which changes the actual picture of humus dynamics considerably. Therefore, the most significant way of solving these issues is a continuous agronomic experiment - the most realistic way of studying the processes of accumulation and mineralization of humus, forecasting the dynamics for the nearest perspective and working out the agrotechnical technologies of regulating it in chernozems.

The mathematical and statistical models have become widely spread recently [18]. It should be noted that the drawback of the suggested models lies in the fact that they do not give an absolutely accurate forecast, the dynamics of humus accumulation or decomposition is a very complicated biochemical process, depending on many factors, which have not been accounted for in the model, and any change in the crop rotation (a set of crops or crop rotation structure, soil tillage, kind of organic fertilizers and their dosage) may lead to the change in a humus state of chernozem. Therefore, periodic study of humus state of chernozems with further correction of the change in coefficients of prognostic equations of humus accumulation or mineralization is required [2, 15]. The work [19] describes the impact of fertilizers on humus dynamics. A relevant task of preserving the fertility of chernozem is forecasting the change in total humus of typical chernozem under longterm application of different technologies of tillage.

The aim of this work is to determine the rates of humus accumulation dynamics and mineralization of total humus and to develop the forecast of the change in its content within a continuous agronomic experiment up to 2050 at the longstanding application of different technologies of soil tillage to typical low humus chernozem of the Left-Bank Forest-Steppe of Ukraine.

\section{MATERIALS AND METHODS}

The studies were conducted in conditions of the central part of the Left-Bank Forest-Steppe of Ukraine during a continuous agronomic experiment in the Drabiv experimental field of the Cherkasy State Agricultural Experimental Station, NSC "Institute of Agriculture", NAAS of Ukraine. The experiment was located on typical low-humus heavy-clay light loamy chernozem with the humus content of $3.8-4.2 \%$, the content of mobile phosphorus - 12-14 mg per $100 \mathrm{~g}$ of soil, and that of mobile potassium $-8-10 \mathrm{mg}$ per $100 \mathrm{~g}$ of soil, $\mathrm{pH}_{\mathrm{c}}=6.8-7.0$. The study involved two five-field crop rotations: perennial grasses-winter wheat-sugar beetcorn-barley with some sown grasses (crop rotations: $60 \%$ - grains, $20 \%$ - technical crops, perennial grasses - $20 \%$ ). Fertilization system (1995-2017): no fertilizers and $\mathrm{N}_{33-66} \mathrm{P}_{31-62} \mathrm{~K}_{41-82}$ per 1 ha of crop rotation + 6-7 t/ha of by-products. Until 1995 manure was introduced in the amount of $6 \mathrm{t} / \mathrm{ha}$ with the similar dose of mineral fertilizers. The technologies of soil tillage in five-field crop rotations: ploughing of different depth for $22-25 \mathrm{~cm}$; subsurface tillage for $22-25 \mathrm{~cm}$; and surface tillage for $10-12 \mathrm{~cm}$. The content of total humus was determined according to I. V. Turin in the modification of M. V. Simakov (DSTU 4289:2004). The content of humus in the humus horizon as of 1925 was studied using the research materials of the Drabiv experimental station, prepared by Kh. G. Zinovieva [20]. Three factors were considered while analyzing the centennial cycle of total humus dynamics: a type of organic fertilizers, a technology of tillage and a crop rotation with perennial grasses.

Forecasting of the change in the humus state of chernozem under different technologies of tillage was conducted for each separate technology of soil tillage. Thus, the impact factor was deemed to be the number of years after $1925\left(t_{1}=92\right)$ and after the start of the experiment $-1975\left(t_{2}=42\right.$ years $)$. The logarithmic parametric function was selected as a functional dependency: $\mathrm{y}=\alpha \pm \beta \ln \mathrm{x}$, where: $\mathrm{y}$ - unknown parameter (humus content); $\alpha$ - coefficient of parametric function; $\beta$ - coefficient related to the explanatory factor; ln - natural logarithm; $x$ - quantitative characteristic $(\mathrm{t}$ - time). The results of field studies were statistically processed by the dispersion analysis method (B. O. Dospiekhov, 1985) using Statistica-8 software.

\section{RESULTS OF INVESTIGATIONS}

As of 1925, the humus content in chernozems of the Drabiv experimental field was $6.49 \%$ while keeping the fallow in the $0-20 \mathrm{~cm}$ layer, and $5.12 \%$ - in the 

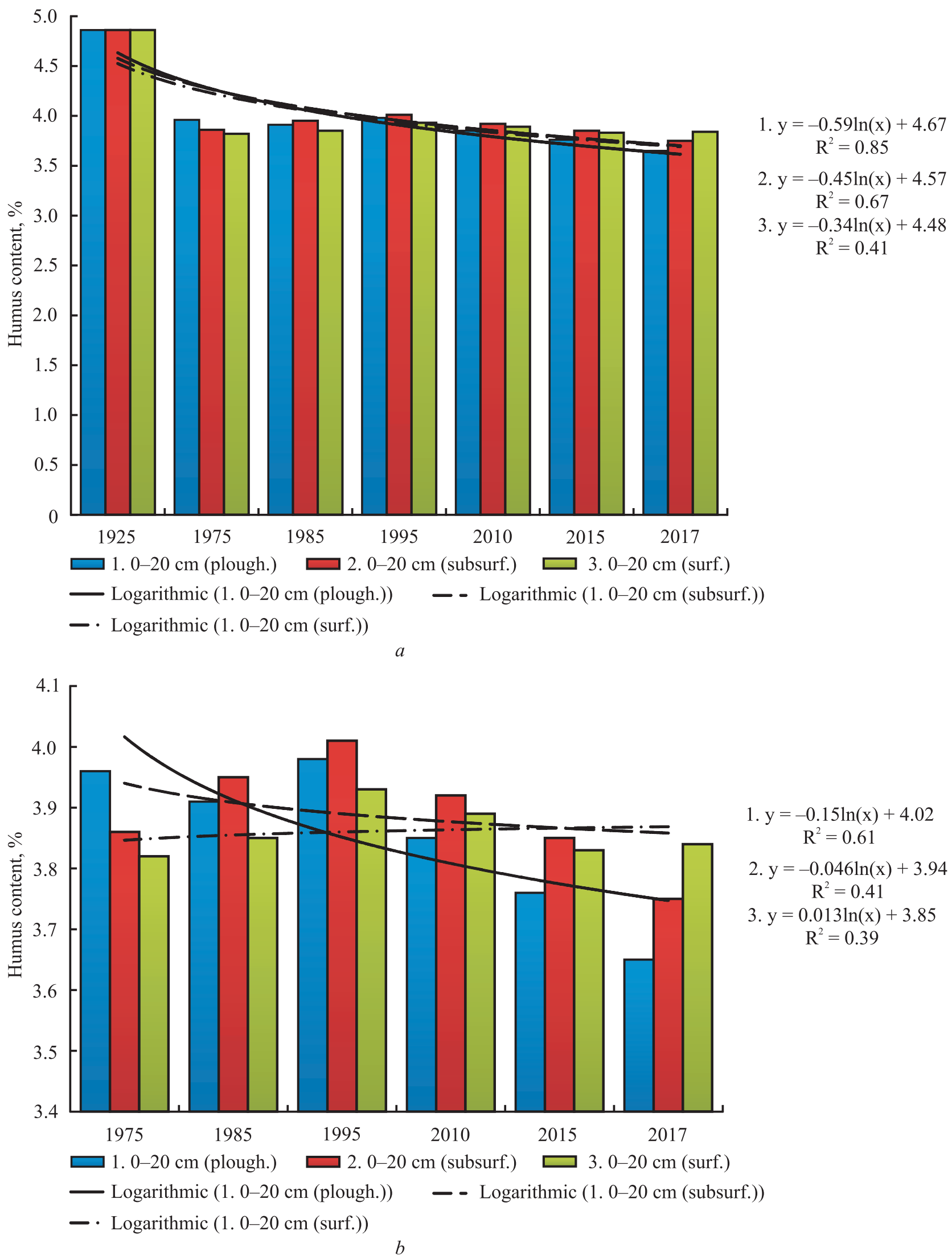

Fig. 1. The dynamics of the change in total humus content depending on the tillage technology of typical chernozem: in 1925-2017 (a) and in 1975-2017 (b) 


\section{DEMYDENKO et al.}

humus horizon $(0-40 \mathrm{~cm})$. There were $4.86 \%$ and $4.56 \%$ in the variant of intense use of chernozem under tillage respectively (Fig. 1,a).

The decrease in humus content relative to the fallow was $0.63 \%$ and $0.16 \%$. In 1975 the content of total humus as of the start of the continuous experiment was $3.82-3.96 \%(0-20 \mathrm{~cm})$ and $3.65-3.79 \%(0-40 \mathrm{~cm})$.

In 50 years (1925-1975), typical chernozems lost $28-30 \%$ and $21-23 \%$ of humus compared to the con- tent in the fallow, and in case of the intense use of chernozem - 19-21\% and 18-20\% in the soil layers of $0-20 \mathrm{~cm}$ and $0-40 \mathrm{~cm}$ respectively.

In 1975 the experiment was started with the purpose of continuous study of the impact of different technologies of chernozem tillage on the change in the humus state (Fig. 1, b). Until 1995, the gradient of change in the humus content compared to 1925 fluctuated inconsiderably either decreasing or increasing regardless of

Table 1. The dynamics of the change in the total humus under the impact of different technologies of tillage of typical lowhumus chernozem in 1925-2017

\begin{tabular}{|c|c|c|c|c|c|c|c|}
\hline \multirow{4}{*}{ Years } & \multicolumn{7}{|c|}{ Technologies of soil tillage } \\
\hline & \multicolumn{2}{|c|}{ ploughing } & \multicolumn{2}{|c|}{ subsurface } & \multicolumn{2}{|c|}{ surface } & \multirow{3}{*}{$\begin{array}{l}\text { Period after } \\
\text { start of } \\
\text { experiment }\end{array}$} \\
\hline & $0-20 \mathrm{~cm}$ & $0-40 \mathrm{~cm}$ & $0-20 \mathrm{~cm}$ & $0-40 \mathrm{~cm}$ & $0-20 \mathrm{~cm}$ & $0-40 \mathrm{~cm}$ & \\
\hline & \multicolumn{6}{|c|}{ Content of humus, $\%$} & \\
\hline 1925 & 4.86 & 4.56 & 4.86 & 4.56 & 4.86 & 4.56 & - \\
\hline *1975 & 3.96 & 3.79 & 3.86 & 3.75 & 3.82 & 3.65 & 50 \\
\hline 1985 & 3.91 & 3.87 & 3.95 & 3.81 & 3.85 & 3.66 & 10 \\
\hline 1995 & 3.98 & 3.85 & 4.02 & 3.87 & 3.98 & 3.71 & 20 \\
\hline 2010 & 3.85 & 3.78 & 3.92 & 3.83 & 3.95 & 3.66 & 35 \\
\hline 2015 & 3.66 & 3.62 & 3.85 & 3.89 & 4.01 & 3.71 & 40 \\
\hline 2017 & 3.45 & 3.41 & 3.75 & 3.65 & 4.03 & 3.68 & 42 \\
\hline \multicolumn{8}{|c|}{ Gradient of the change in humus content compared to $1925, \%$} \\
\hline 1975 & -0.90 & -0.77 & -1.00 & -0.81 & -0.69 & -0.91 & - \\
\hline 1985 & -0.05 & 0.08 & 0.09 & 0.06 & -0.09 & 0.01 & 10 \\
\hline 1995 & 0.07 & -0.02 & 0.07 & 0.06 & -0.05 & 0.05 & 20 \\
\hline 2010 & -0.13 & -0.07 & -0.10 & -0.04 & -0.05 & -0.05 & 35 \\
\hline 2015 & -0.19 & -0.16 & -0.07 & 0.06 & -0.02 & 0.16 & 40 \\
\hline 2017 & -0.21 & -0.21 & -0.10 & -0.24 & -0.03 & -0.03 & 42 \\
\hline \multicolumn{8}{|c|}{ \pm humus compared to 1925} \\
\hline- & -1.41 & -1.15 & -1.11 & -0.91 & -0.83 & -0.88 & 52 \\
\hline \multicolumn{8}{|c|}{ Average estimated mineralization/formation of humus for 92 years, $\%$ a year } \\
\hline- & -0.0153 & -0.0125 & -0.012 & -0.0121 & -0.009 & -0.010 & - \\
\hline \multicolumn{8}{|c|}{ \pm humus compared to 1975} \\
\hline- & -1.51 & -1.38 & -1.11 & -1.10 & 1.21 & 0.03 & 42 \\
\hline \multicolumn{8}{|c|}{ Average estimated mineralization/formation of humus for 42 years, $\%$ a year } \\
\hline- & -0.0121 & -0.0091 & -0.003 & -0.0026 & 0.005 & +0.0007 & - \\
\hline \multicolumn{8}{|c|}{ \pm humus from ploughing (control) } \\
\hline- & - & - & +0.30 & +0.24 & +0.68 & +0.27 & - \\
\hline
\end{tabular}

Note. $* 1975$ - year of starting the experiment. 


\section{LONG-TERM DYNAMICS OF HUMUS CONTENT UNDER DIFFERENT TECHNOLOGIES OF SOIL TILLAGE}

the technology of tillage, which is related to the period of introducing the manure in the amount of $30 \mathrm{t} / \mathrm{ha}$ for sugar beet or $6 \mathrm{t} / \mathrm{ha}$ of the crop rotation (Table 1). Typical chernozem passed from medium-humus gradation into low-humus gradation. Likely this is due to the fact that the dehumification passed to relatively quasi-equilibrium state with the formation of humus at a certain level of organics intake into soil and the stability of the fertilization system.

From 1995 till 2017, when by-products were introduced instead of manure, the gradient of humus content under ploughing was $0.13-0.21 \%(0-20 \mathrm{~cm})$ and $0.07-0.21 \%(0-40 \mathrm{~cm})$, while under systematic application of subsurface tillage in the $0-20 \mathrm{~cm}$ soil layer the humus content decreased by $0.07-0.10 \%$, and by $0.04-0.24 \%-$ in the $0-40 \mathrm{~cm}$ of chernozem layer. The regularity, found for the subsurface tillage, was even more manifested under surface tillage.

It was determined that regardless of the technology of tillage, there was further dehumification of chernozem, and the decrease in humus content depended on the intensity of tillage. The average estimated annual mineralization of humus for 52 years was in agreement with the found regularity and had the lowest values under surface tillage $(0.009-0.01 \%$ per year). Under ploughing, the gradient of change in the humus content in 1975 was negative $(-0.51$ and $-0.38 \%)$; under subsurface tillage the gradient of humus decrease was 3.8-4.6 times lower than that for ploughing, and the surface tillage demonstrated the increase in the humus content by +0.21 and $+0.03 \%$.

Under ploughing, the average estimated mineralization of humus for 42 years was the highest and decreased 3.5-4 times under subsurface tillage; and under surface tillage the annual increase in the humus content was +0.005 and $+0.0007 \%$ relative to soil layers. The logarithmic equations of dynamics trends for the total humus for 92 years had a declining character with the reliable level of approximation $\left(\mathrm{R}^{2}>0.4\right)$ regardless of the technology of chernozem tillage, and the regression coefficients $(\mathrm{Cr})$ for the variable $\mathrm{x}(\mathrm{t})$ were negative. Under subsurface tillage, $\mathrm{Cr}$ decreased 1.31-1.75 times in the 0-20 soil layer, and 1.43 times in the humus horizon $(0-40 \mathrm{~cm})$ which testifies to the decrease in the mineralization rate per one time unit. The estimation of logarithmic equations and trends of declining dynamics of the total humus during the period of studying the efficiency of different technologies of tillage (19752017) demonstrated the reliability of the approximation of trends $\left(\mathrm{R}^{2}>0.40\right)$. Under ploughing in the 0
$20 \mathrm{~cm}$ chernozem layer, the regression coefficient for the variable $\mathrm{x}(\mathrm{t})$ was 3.26 times higher compared to the regression coefficients of the trends for the subsurface tillage, and under surface tillage the regression coefficient for the variable $\mathrm{x}$ was positive and 11-12 times higher, which testifies to the increasing character of the humus accumulation trend.

In the humus horizon $(0-40 \mathrm{~cm})$, the trends of humus dynamics had a declining character regardless of the technology of tillage, but under ploughing the value of Cr was 5.5-11 times higher compared to the subsurface and surface technologies of tillage, which testifies to the decrease in the rate of humus mineralization in the latter two cases.

While preserving and restoring the humus in chernozem, a relevant task is to forecast the changes in the humus content under long-term application of different technologies of soil tillage, which is complicated and possible only in conditions of a continuous agronomic experiment. The parametric logarithmic functions were used to estimate the theoretical (forecast) content of total humus in typical chernozem under different variants of chernozem tillage till 2050. The values, obtained about the anticipated humus content, were used to estimate the theoretical (forecast) humus balance relative to 1975 (Fig. 2, a).

It was established that under systematic ploughing the humus content will decrease in the most intense way compared to subsurface and surface technologies. It is on the highest level in the $0-20 \mathrm{~cm}$ chernozem layer. Under ploughing, the regression coefficients for the variable $\mathrm{x}(\mathrm{t})$ in the regression equations are 1.35-1.55 times higher compared to the subsurface and surface technologies of tillage. This regularity is less expressed in the humus horizon, but the regression coefficients at $\mathrm{x}(\mathrm{t})$ for subsurface tillage are 1.18-1.23 times lower. In all the cases, the regression coefficients were negative, which testified to the declining rate of humus accumulation. By the declining trend, the humus content in its absolute manifestation in the $0-20 \mathrm{~cm}$ soil layer would be $2.35 \%$ (2025) and $2.11 \%$ (2050) for systematic ploughing; $2.85 \%$ and $2.65 \%$ - for subsurface tillage; $3.15 \%$ and $2.66 \%$ - for surface tillage. The change in the total humus content in the humus horizon $(0-40 \mathrm{~cm})$ is subject to the found regularity for the 0-20 cm chernozem layer in accordance to the years of forecasting (2025 and 2050) and the technologies of chernozem tillage (Table 1).

The estimation of the humus balance demonstrated that regardless of the technology of tillage, in 2017 
DEMYDENKO et al.
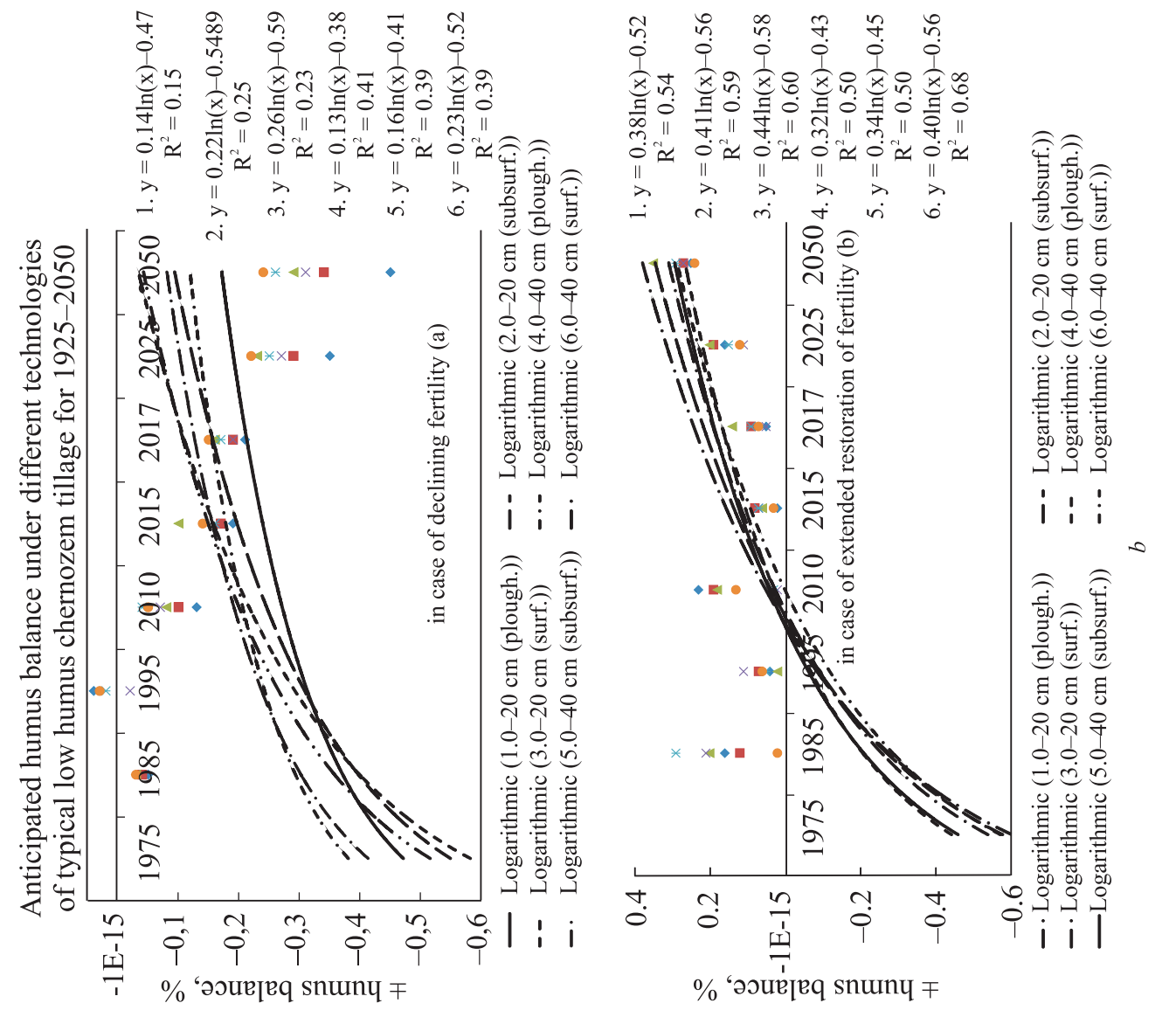

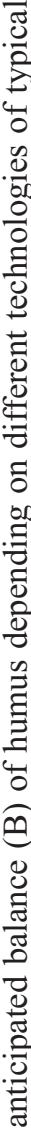
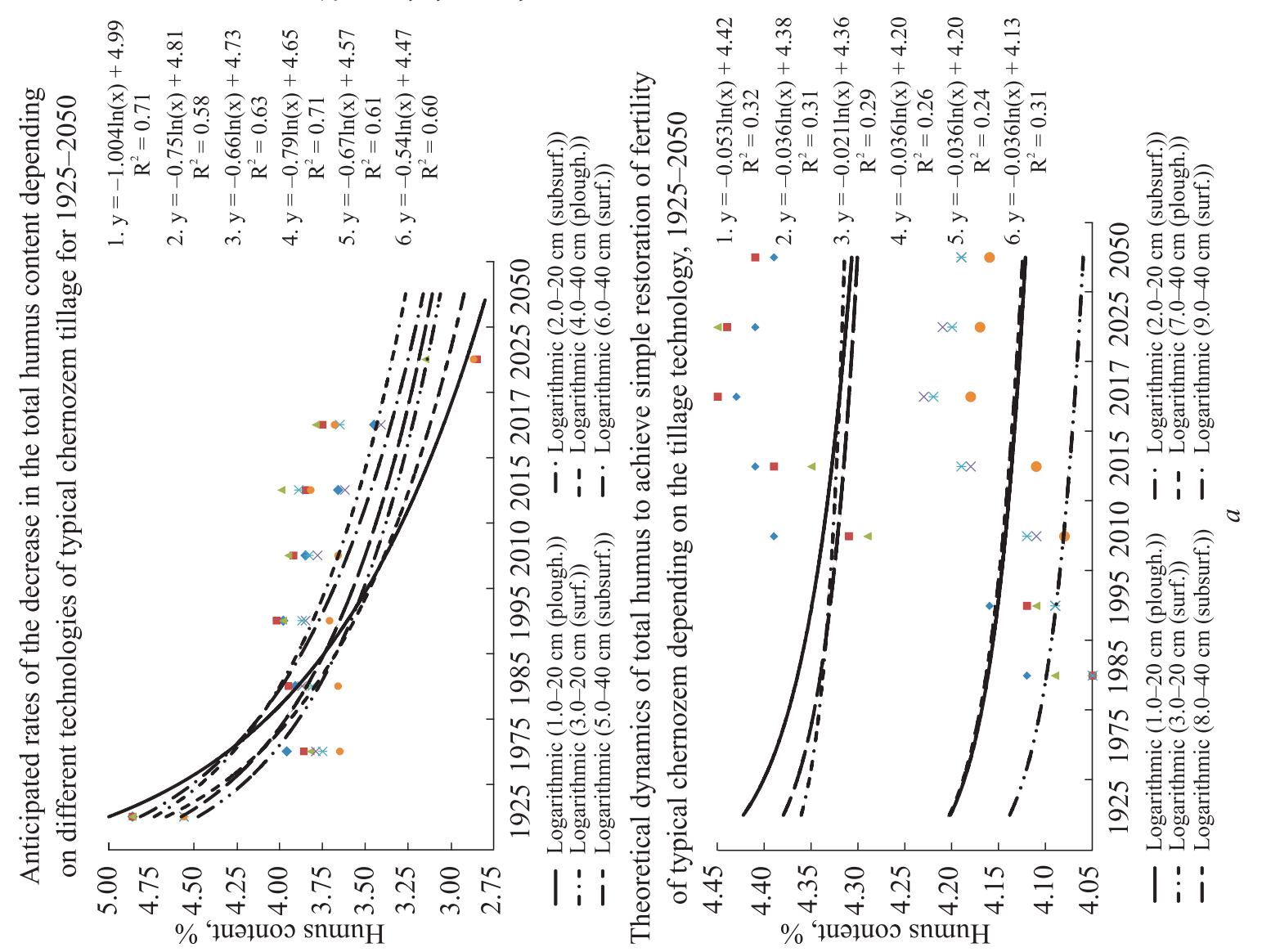

尔

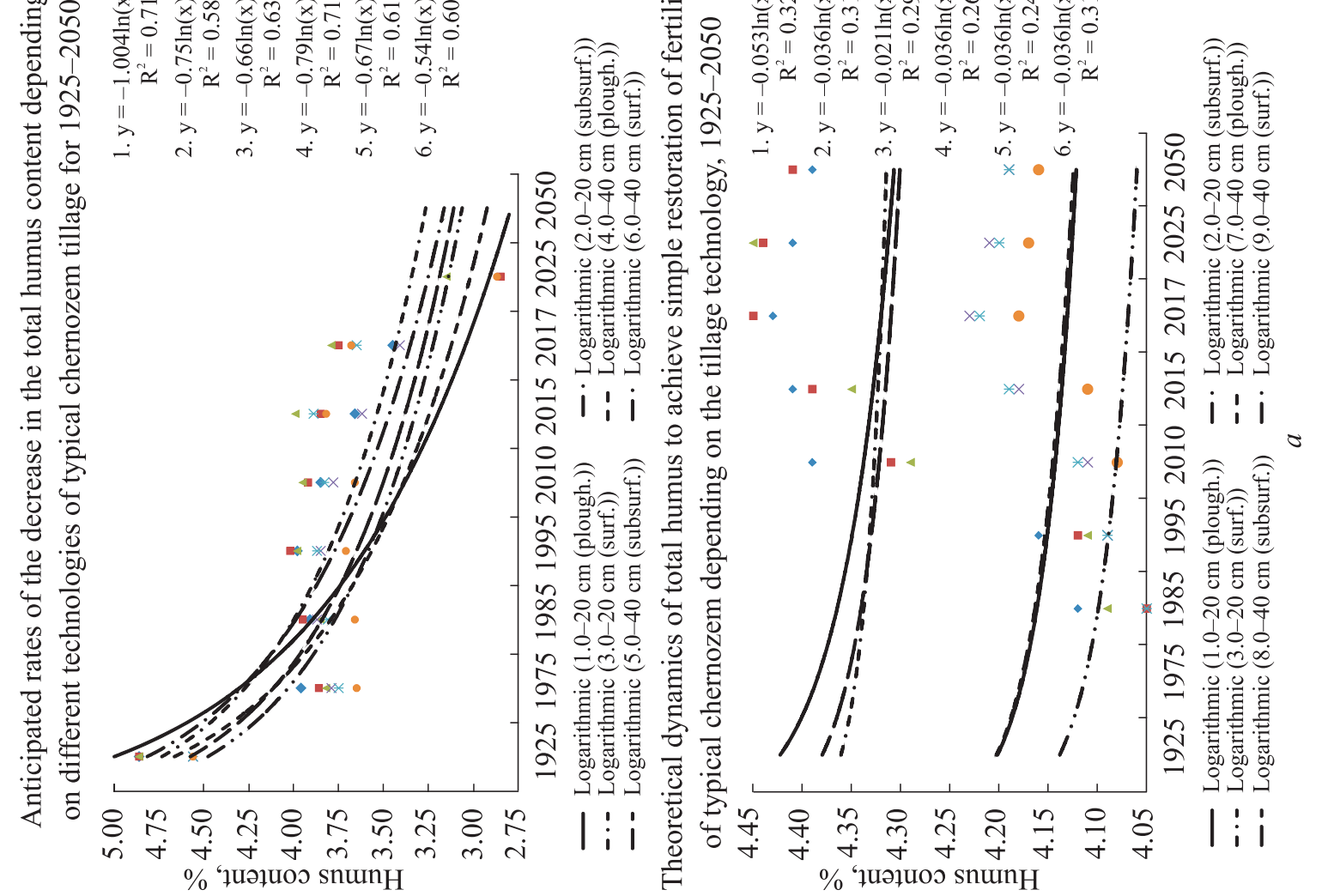

\&

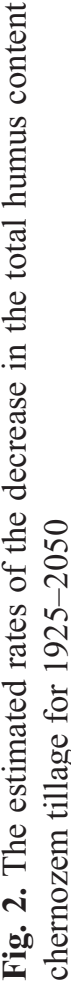




\section{LONG-TERM DYNAMICS OF HUMUS CONTENT UNDER DIFFERENT TECHNOLOGIES OF SOIL TILLAGE}

the humus balance was negative, and its deficiency decreased from ploughing $(-0.19-0.21 \%)$ to the surface tillage $(-0.15-0.17 \%)$. Under subsurface tillage the value of the humus balance had interim values: $-0.16-0.19 \%$. Compared to 1975 , the estimated humus balance till 2050 has an increasing trend, but regardless of the technology of soil tillage, the humus balance acquires a negative value, and the increase in the intensity of soil tillage (ploughing) increases the deficiency of humus balance, which rises, compared to the subsurface and surface technologies of tillage, 1.55-3.31 times and 1.19-1.31 times higher in the $0-20 \mathrm{~cm}$ and 0-40 cm soil layer (Fig. 2, b).

The increasing character of trends of humus balance is determined by a high rate of humus accumulation in 1975-1995, when manure was introduced as an organic fertilizer (6-7 t/ha). When manure was replaced with by-products, the rate of the increase in the deficiency of humus balance rose actively, by 2050 they are estimated to reach negative values at the level of $-0.29 \%$ for subsurface tillage and the values, exceeding $-0.40 \%$, for systematic ploughing. In general, the estimated trends in humus balance by 2050 are of increasing character, but they are not likely to reach the zero value. By the regression coefficients, the rate of deficiency increase in the humus balance is 1.85-2.0 times more intense for ploughing compared to the subsurface tillage.

Regardless of the fact that for 42 years of experiment, the humus content was not preserved at the initial level (1975), the application of subsurface and surface technologies of tillage promoted the increase in its content in humus horizon compared to the ploughing. In 2017 the content of total humus was determined in different variants of soil tillage. It was determined that the application of subsurface technologies of soil tillage led to considerable slowing down of the dehumification processes and resulted in some stabilization of the humus content but did not promote its extended restoration. The increase in the content of total humus was determined only compared to ploughing and the control, where the fertilizers were not introduced. The stabilization of humus content took place in the declining trend compared to the control point of the humus content both in 1925 and in 1975, when the experiment was started. The extended restoration of humus took place while keeping the fallow ( $+0.022 \%$ a year): for 42 years of keeping the fallow, humus was restored by 95-97\% compared to 1925 , and while keeping the fallow for more than 54 years - by $113 \%$ (Fig. 3).
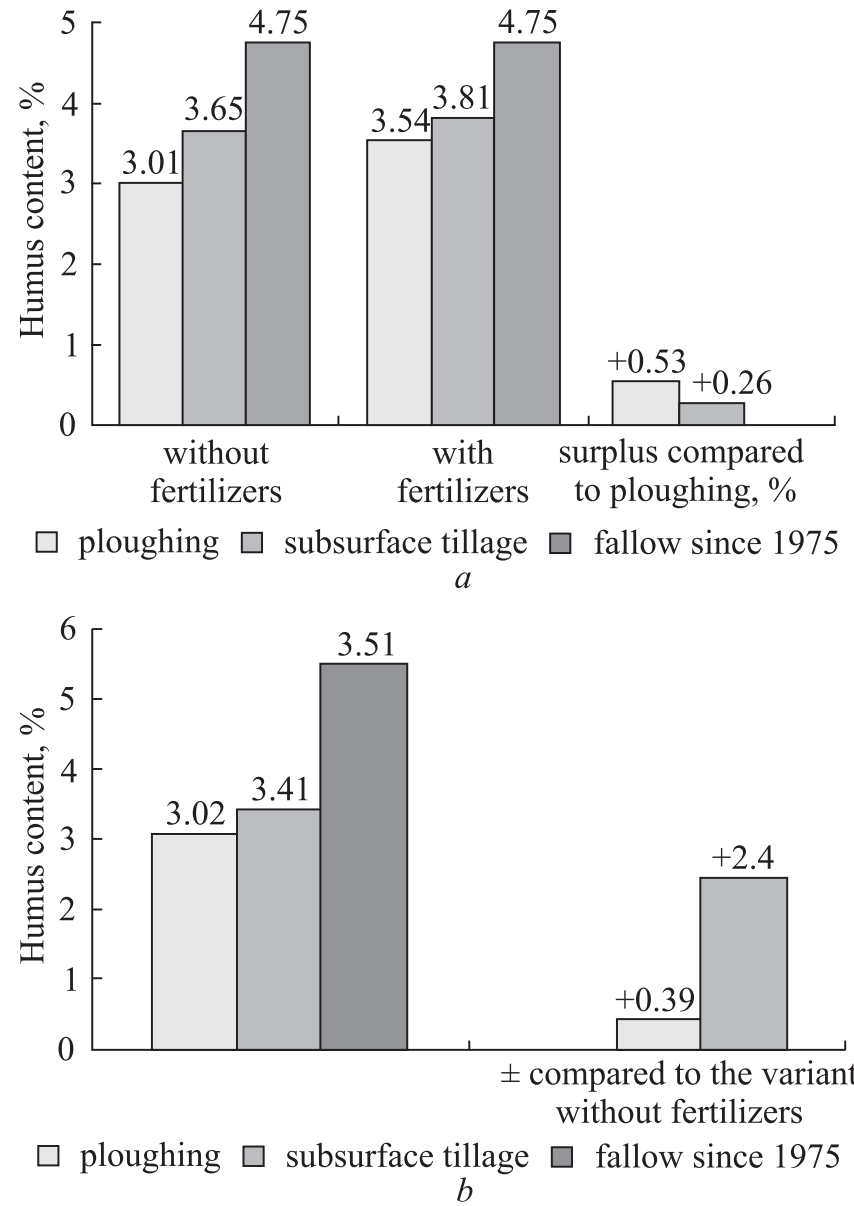

Fig. 3. Humus state of typical low humus chernozem depending on the technology of tillage and fertilization $(a)$ : 42 years of experiment; fertilization $(b)$ in ten-field graingrowing and weeding crop rotation: 54 years of experiment; keeping the fallow for 42 and 54 years respectively, $a$ and $b$

There is a logical question - which rate of humus accumulation and increase in humus balance should be ensured to reach the edge of transition from the declining trend to the increasing one? The evaluation demonstrated (Table 2) that in 2017 it was necessary to ensure $4.41-4.43 \%$ humus content in the $0-20 \mathrm{~cm}$ of soil layer and $4.18-4.23 \%-$ in the humus horizon. It was determined that to reach the level of transition to the increasing trend of humus accumulation, one should reach the $4.65-4.67 \%$ humus content in the $0-40 \mathrm{~cm}$ chernozem layer for ploughing and $4.39-4.41 \%$ - for subsurface tillage. Therefore, it is necessary to ensure the increase in the humus content by $11.6-11.9 \%$ and $16.4-17.9 \%$ for ploughing; $12.8-12.9 \%$ and $15.8-20.9 \%$ for subsurface tillage and $13.3-13.4 \%$ and $19.7 \%$ for surface tillage, relative to the level of restoration of fertility and soil layers. In case of such provision of the humus content, the average estimated mineralization of humus 


\section{DEMYDENKO et al.}

Table 2. The estimated dynamics of the total humus under the impact of different technologies of tillage of typical low humus chernozem in 1925-2017

\begin{tabular}{|c|c|c|c|c|c|c|c|}
\hline \multirow{3}{*}{ Years } & \multicolumn{7}{|c|}{ Technologies of soil tillage } \\
\hline & \multicolumn{2}{|c|}{ ploughing } & \multicolumn{2}{|c|}{ subsurface } & \multicolumn{2}{|c|}{ surface } & \multirow{2}{*}{$\begin{array}{l}\text { Period after } \\
\text { start of } \\
\text { experiment }\end{array}$} \\
\hline & $0-20 \mathrm{~cm}$ & $0-40 \mathrm{~cm}$ & $0-20 \mathrm{~cm}$ & $0-40 \mathrm{~cm}$ & $0-20 \mathrm{~cm}$ & $0-40 \mathrm{~cm}$ & \\
\hline
\end{tabular}

To reach the positive trend of increasing - simple restoration of humus

\begin{tabular}{|c|c|c|c|c|c|c|c|}
\hline \multicolumn{8}{|c|}{ Content of humus, $\%$} \\
\hline 1925 & 4.86 & 4.56 & 4.86 & 4.56 & 4.86 & 4.56 & - \\
\hline *1975 & 3.96 & 3.79 & 3.93 & 3.75 & 3.89 & 3.69 & 50 \\
\hline 2017 & 4.43 & 4.23 & 4.45 & 4.22 & 4.41 & 4.18 & 42 \\
\hline \multicolumn{8}{|c|}{ Gradient of decline/increase in humus compared to $1925, \%$} \\
\hline 1975 & -0.90 & -0.77 & -0.93 & -0.81 & -0.97 & -0.87 & - \\
\hline 2017 & +0.05 & +0.05 & +0.06 & +0.05 & +0.07 & +0.07 & 42 \\
\hline \multicolumn{8}{|c|}{ \pm humus as of 1925} \\
\hline- & -1.43 & -0.33 & -1.41 & -0.34 & -0.45 & -0.38 & 92 \\
\hline
\end{tabular}

Average estimated mineralization/formation of humus for 92 years, \% a year

\begin{tabular}{c|c|c|c|c|c|c|c|c}
\hline- & -0.0047 & -0.0036 & -0.0045 & -0.0037 & -0.0049 & -0.0041 & - \\
\hline \multicolumn{7}{c}{ \pm humus compared to 1975} \\
\hline- & +0.47 & +0.44 & +0.51 & +0.47 & +0.52 & +0.49 & 42 \\
\hline
\end{tabular}

Average estimated mineralization/formation of humus for 42 years, $\%$ a year

\begin{tabular}{l|l|l|l|l|l|l}
- & +0.0112 & +0.0105 & +0.0121 & +0.0112 & +0.0124 & +0.0117
\end{tabular}

For stable transition to the positive trend of increasing - extended restoration of humus

Content of humus, $\%$

\begin{tabular}{|c|c|c|c|c|c|c|c|}
\hline $\begin{array}{c}1925 \\
* 1975 \\
2017\end{array}$ & $\begin{array}{l}4.86 \\
3.96 \\
4.67\end{array}$ & $\begin{array}{l}4.56 \\
3.79 \\
4.41\end{array}$ & $\begin{array}{l}4.86 \\
3.86 \\
4.67\end{array}$ & $\begin{array}{l}4.56 \\
3.81 \\
4.41\end{array}$ & $\begin{array}{l}4.86 \\
3.85 \\
4.67 \\
\end{array}$ & $\begin{array}{l}4.56 \\
3.75 \\
4.39\end{array}$ & $\begin{array}{l}- \\
50 \\
42\end{array}$ \\
\hline \multicolumn{8}{|c|}{ Gradient of decline/increase in humus compared to $1925, \%$} \\
\hline $\begin{array}{l}1975 \\
2017\end{array}$ & $\begin{array}{l}-0.90 \\
+0.09\end{array}$ & $\begin{array}{l}-0.77 \\
+0.09\end{array}$ & $\begin{array}{l}-1.00 \\
+0.13\end{array}$ & $\begin{array}{l}-0.75 \\
+0.08\end{array}$ & $\begin{array}{l}-1.01 \\
+0.12\end{array}$ & $\begin{array}{l}-0.81 \\
+0.09\end{array}$ & $\begin{array}{l}- \\
42\end{array}$ \\
\hline \multicolumn{8}{|c|}{ \pm humus compared to 1925} \\
\hline- & -0.19 & -0.15 & -0.19 & -0.16 & -0.19 & -0.17 & 92 \\
\hline \multicolumn{8}{|c|}{ Average estimated mineralization/formation of humus for 92 years, $\%$ a year } \\
\hline- & -0.0021 & -0.0016 & -0.0022 & -0.0016 & -0.0021 & -0.0019 & - \\
\hline \multicolumn{8}{|c|}{ \pm humus compared to 1975} \\
\hline- & +0.71 & +0.62 & +0.81 & +0.60 & +0.76 & +0.74 & 42 \\
\hline
\end{tabular}

Average estimated mineralization/formation of humus for 42 years, $\%$ a year

\begin{tabular}{l|l|l|l|l|l|l}
- & +0.017 & +0.015 & +0.019 & +0.014 & +0.018 & +0.018
\end{tabular}

Note. $* 1975$ - year of starting the experiment. 


\section{LONG-TERM DYNAMICS OF HUMUS CONTENT UNDER DIFFERENT TECHNOLOGIES OF SOIL TILLAGE}

Table 3. Statistical parameters and fractal dimensionality of the trends of time series of total humus depending on the technology of chernozem tillage by actual and estimated models of development

\begin{tabular}{|c|c|c|c|c|c|c|}
\hline $\begin{array}{l}\text { Depth, } \\
\text { cm }\end{array}$ & $\begin{array}{l}\text { Equation of } \\
\text { trend exponent }\end{array}$ & $* \mathrm{R}^{2}$ & Coef. var, \% & $\begin{array}{c}* * 0.46 \text { Coef. } \\
\text { var, } \%\end{array}$ & $* * * \mathrm{I}_{\mathrm{f}}$ & $* * * * \mathrm{FR}$ \\
\hline \multicolumn{7}{|c|}{ Indices by actual determinations, 1925-2017 } \\
\hline \multicolumn{7}{|c|}{ Ploughing $-75-100$ years } \\
\hline $\begin{array}{l}0-20 \\
0-40\end{array}$ & $\begin{array}{l}Y=4.70 e^{-0.045 x} \\
Y=4.41 e^{-0.035 x}\end{array}$ & $\begin{array}{l}0.79 \\
0.73\end{array}$ & $\begin{array}{l}36.1 \\
15.7\end{array}$ & $\begin{array}{l}16.6 \\
7.23\end{array}$ & $\begin{array}{l}-0.045 \\
-0.035\end{array}$ & $\begin{array}{l}1.05 \\
1.04\end{array}$ \\
\hline \multicolumn{7}{|c|}{ Subsurface tillage -42 years } \\
\hline $\begin{array}{l}0-20 \\
0-40\end{array}$ & $\begin{array}{l}Y=4.51^{e-0.028 x} \\
Y=4.25 e^{-0.021 x}\end{array}$ & $\begin{array}{l}0.51 \\
0.49\end{array}$ & $\begin{array}{l}23.8 \\
19.6\end{array}$ & $\begin{array}{l}10.9 \\
9.00\end{array}$ & $\begin{array}{l}-0.028 \\
-0.021\end{array}$ & $\begin{array}{l}1.03 \\
1.02\end{array}$ \\
\hline \multicolumn{7}{|c|}{ Surface tillage -2 years } \\
\hline $\begin{array}{l}0-20 \\
0-40\end{array}$ & $\begin{array}{l}Y=4.28 \mathrm{e}^{-0.014 x} \\
Y=4.08 \mathrm{e}^{-0.016 x}\end{array}$ & $\begin{array}{l}0.41 \\
0.39\end{array}$ & $\begin{array}{l}28.1 \\
17.9\end{array}$ & $\begin{array}{l}12.9 \\
8.22\end{array}$ & $\begin{array}{l}-0.014 \\
-0.016\end{array}$ & $\begin{array}{l}1.01 \\
1.02\end{array}$ \\
\hline \multicolumn{7}{|c|}{ Indices by estimated determinations, $1925-2050$} \\
\hline \multicolumn{7}{|c|}{ Ploughing - 75-100 years } \\
\hline $\begin{array}{l}0-20 \\
0-40\end{array}$ & $\begin{array}{l}Y=5.61^{e-0.098 x} \\
Y=4.95 e-0.072 x\end{array}$ & $\begin{array}{l}0.87 \\
0.41\end{array}$ & $\begin{array}{l}35.0 \\
20.0\end{array}$ & $\begin{array}{l}16.1 \\
9.20\end{array}$ & $\begin{array}{l}-0.098 \\
-0.072 \\
\end{array}$ & $\begin{array}{l}1.10 \\
1.07\end{array}$ \\
\hline \multicolumn{7}{|c|}{ Subsurface tillage -42 years } \\
\hline $\begin{array}{l}0-20 \\
0-40\end{array}$ & $\begin{array}{l}Y=5.09^{e-0.061 x} \\
Y=4.59^{e-0.046 x}\end{array}$ & $\begin{array}{l}0.56 \\
0.56\end{array}$ & $\begin{array}{l}25.0 \\
19.0\end{array}$ & $\begin{array}{l}11.5 \\
8.74\end{array}$ & $\begin{array}{l}-0.061 \\
-0.046\end{array}$ & $\begin{array}{l}1.06 \\
1.05\end{array}$ \\
\hline \multicolumn{7}{|c|}{ Surface tillage -42 years } \\
\hline $\begin{array}{l}0-20 \\
0-40\end{array}$ & $\begin{array}{l}Y=4.67^{\mathrm{e}-0.047 \mathrm{x}} \\
\mathrm{Y}=4.44 \mathrm{e}^{-0.040 \mathrm{x}}\end{array}$ & $\begin{array}{l}0.44 \\
0.47\end{array}$ & $\begin{array}{l}27.0 \\
16.0\end{array}$ & $\begin{array}{l}12.4 \\
7.36\end{array}$ & $\begin{array}{l}-0.047 \\
-0.040\end{array}$ & $\begin{array}{l}1.05 \\
1.04\end{array}$ \\
\hline
\end{tabular}

Indices by the model forecasting of simple restoration of fertility,

$1925-2050$

\begin{tabular}{|c|c|c|c|c|c|c|}
\hline \multicolumn{7}{|c|}{ Ploughing $-75-100$ years } \\
\hline $0-20$ & $Y=4.28 \mathrm{e}^{0.0098 \mathrm{x}}$ & 0.29 & - & - & 0.0098 & 1.01 \\
\hline $0-40$ & $Y=4.07 e^{0.0091 x}$ & 0.25 & - & - & 0.0091 & 1.01 \\
\hline \multicolumn{7}{|c|}{ Subsurface tillage -42 years } \\
\hline $0-20$ & $\mathrm{Y}=4.21 \mathrm{e}^{0.017 \mathrm{x}}$ & 0.23 & - & - & 0.017 & 1.02 \\
\hline $0-40$ & $\mathrm{Y}=4.05 \mathrm{e}^{0.0095 \mathrm{x}}$ & 0.22 & - & - & 0.0095 & 1.01 \\
\hline \multicolumn{7}{|c|}{ Surface tillage -42 years } \\
\hline $0-20$ & $Y=4.20 \mathrm{e}^{0.0195 \mathrm{x}}$ & 0.22 & - & - & 0.021 & 1.02 \\
\hline $0-40$ & $Y=4.05 \mathrm{e}^{0.016 \mathrm{x}}$ & 0.19 & - & - & 0.016 & 1.02 \\
\hline
\end{tabular}

Note. $* \mathrm{R}^{2}-$ value of approximation reliability; $* * 0.46 *$ Coef.var, $\%$ - approximation curve deviation; $* * * \mathrm{I}_{\mathrm{f}}$ - indicator of fractality; ****FR - fractal dimensionality: $\left(\mathrm{FR}=1-\mid \mathrm{I}_{\mathrm{f}}\right),[23]$. 


\section{DEMYDENKO et al.}

in the 92-year-long cycle should be $0.0036-0.0049 \%$, and the increase in the humus content in the 42 -yearold cycle $-0.00112-0.0124 \%$ a year.

The increasing trend of humus accumulation in the 92-year-long cycle is ensured at the background of average estimated mineralization of humus in the range of $0.0016-0.0021 \%$, which is $2.25-2.33$ times lower than the variant of approximation to the conditions of the increasing trend and 7.3-7.5 times lower than the actual mineralization for 1975-2017.

The forecast and estimation of the behavior of the dynamic soil system include the evaluation and assessment of fractal dimensionality of time series of integral soil parameters, which may involve the dynamics of total humus and fertility of chernozems in agroecosystems. The determination of fractal dimensionality of time series of linear systems is based on the change in the curve length depending on the scale. If the curve is estimated as a fractal one, the length of the curve will increase with the decrease of the scale in an exponential way [21-24].

The analysis of statistical parameters and fractal dimensionality of the trends of time series of humus in the centennial cycle depending on the technology of soil tillage and according to actual and prognostic indices demonstrated (Table 3 ) that regardless of the technology of chernozem tillage, the equations of exponential trends have a declining character at the reliable value of approximation $\left(\mathrm{R}^{2}=0.41-0.79\right)$ and the reliable deviation of the approximation curve $\left(0.46^{*}\right.$ Coef. var, $\%=7.23-16.6)$ : the regression coefficients $(-b)$ for the variable $\left(a^{*} e^{-b x}\right)$ have a negative value. Under soil-protective technologies of chernozem tillage, the values of the regression coefficients were 1.6-1.7 times lower (subsurface tillage) and 2.19-3.31 times lower at the surface tillage, which demonstrated a slower character of dehumification in the centennial cycle. The determination of the fractality indicator $\left(\mathrm{I}_{f}\right)$ as a degree of approximating exponential function, giving low and positive values of the argument (x) allows for a conclusion about the stable process of the declining humus state of chernozem regardless of the technology of tillage, introduction of different kinds of organic and mineral fertilizers.

The estimation of fractal dimensionality (FR) demonstrated [23] that FR values correspond to the stability interval of the declining development of the soil system $(\mathrm{FR}=1.01-1.41)$ regardless of the technology of soil tillage. If the value of FR $<1.5$, the impact of factors, forming the declining trend of the humus state of chernozem, will take place steadily in future without any changes and the applied agrotechnical measures (introduction of fertilizers, type of crop rotation, technology of soil tillage, sowing of perennial grasses) will not be able to correct the declining dynamics of humus in the centennial cycles. It is only possible to have the correcting impact, capable of restraining the progressing dehumification of chernozems in agroecosystems to some degree (Table 3).

The value of FR indicates stable dehumification of chernozem after its removal from the quasi-equilibrium state of the virgin field of long-term fallow, thus, one should accept the thought that the process of chernozem dehumification in the agroecosystem is a permanent and time-wise steady process, a necessary "evil" which makes it possible to grow crops in the agroecosystems.

The equations of trends $\left(y=a e^{-b x}\right)$ of the declining dynamics of humus content, depending on time under different technologies of tillage, both actual and anticipated ones, differed in the value of the free member $(\mathrm{a}=4.25-5.61)$ and the degree index $(\mathrm{B}=-0.014 \div-$ 0.061), which impacted the value of $I_{f}$. However, the value of FR was in a narrow range of values $(F R=$ $=1.01-1.07)$, which testified to the proximity of the declining dynamics of humus regardless of the technology of chernozem tillage in the centennial cycle (Table 3).

The simulated trends of time series of total humus, which correspond to the approximation to the simple restoration of fertility in the centennial cycle, are achieved in case when the regression coefficients in the exponential equations with the variable $\left(a^{*} e^{b x}\right)$ are positive. Under soil-protective technologies, the values of regression coefficients increase 1.9-2.3 times compared to ploughing. Here $I_{f}$ acquires positive values regardless of the technologies of soil tillage, and under the impact of agrotechnical measures chernozem as a system comes to the stable process of increasing humus-formation in time (Table 3).

The estimates demonstrated that the increase in the content of total humus, which would be required for simple and extended restoration of humus in the centennial cycle, equaled 25-30 t per 1 ha and 35-40 t per 1 ha respectively. To ensure this increase in the content and reserves of humus for 42 years, it is necessary to introduce $15-18 \mathrm{t}$ of manure per 1 ha for simple restoration of total humus content and 18-20 t per 1 ha for extended restoration annually. In case of replacing manure with by-products, the standardized dose of ma- 


\section{LONG-TERM DYNAMICS OF HUMUS CONTENT UNDER DIFFERENT TECHNOLOGIES OF SOIL TILLAGE}

nure (coefficient 3.5) by the yield of straw is $15-18 \mathrm{t}$ per 1 ha and 18-20 t per 1 ha annually, which is actually impossible in modern industrial conditions.

Discussion of results. Achieving the state of simple and extended accumulation of humus is ensured by the positivity of the trends of humus increase during the continuous experiment (42 years) with simultaneous decrease in dehumification process in the centennial cycle (92 years) which is impossible to neutralize completely. Under the impact of the increasing economic activity of humans involving the use of chernozems, there is a stage in the centennial cycle when its development is directed towards mitigating elementary processes of soil formation, which is related to the development of the processes of dehumification and agrophysical degradation, and, as a result, the decrease in the level of natural and efficient fertility of chernozems in the conditions of natural-anthropogenic soil formation.

The intense use of chernozem (ploughing for over 75-100 years) promotes the decrease in the content of total humus the most, but a sharp decrease in the humus content takes place only during the first 25-30 years after ploughing the fallow and virgin fields. With further "improvement" of chernozems, the processes of humus formation-decomposition get stabilized, whereas with high culture of arable farming the mineralization of humus is somewhat restrained, but here the type of humus formation remains extensive and declining by its trend in the centennial cycle.

Among different components of organic matter of chernozem, detritus is paid special attention, as its amount is directly related to the increase in the content and reserves of total humus [25]. Detritus is capable of accumulating newly formed humus substances and peculiar humic substances (PHS) on its surface, which testifies to its relevant role in improving the agrophysical properties of chernozem. Under ploughing for over 75-100 years, the content of detritus was $28-30 \%$ from the total reserves of humus, and its highest amount was formed in places of localization of afterharvest, root remains and manure, i.e. in the lower part of the humus horizon. Under longterm (over 40 years) subsurface tillage, the reserves of detritus in the humus horizon were 1.16-1.4 times higher compared to the long-term ploughing, and the most considerable accumulation of detritus took place in the $0-20 \mathrm{~cm}$ soil layer, where the total reserves of detritus increased up to $35-38 \%$ from the reserves of the total humus, which is confirmed by the data of other researchers, proving that the content of detritus in the total humus is from $35 \%$ to $40 \%$, and exceeds $40 \%$ in the virgin analogues of chernozems [26].

Detritus is the least stable component of the organic matter, the amount of which in the intensively tilled chernozems decreases due to the impairment of the mutual compensation of the conditions of transforming organic residues and forming humus, which is related to the change in the quantitative and qualitative composition of humus. Under systematic implementation of soil-protective technologies, there is acceleration of the processes of soil formation - the humification coefficients of organic matter increase by $12-15 \%$ compared to ploughing. Their highest number was formed for subsurface tillage at different depths: total reserves in the $0-20 \mathrm{~cm}$ soil layer were $2.8-3.3$ times higher, and in the variant of subsurface tillage for $10-12 \mathrm{~cm}-2.6-$ 2.7 times higher compared to the systematic ploughing.

In case of tillage minimization, there was differentiation of the content of active forms of humus in the humus horizon of chernozem, whereas under ploughing the differentiation was manifested inconsiderably. Under subsurface tillage for $10-12 \mathrm{~cm}$, the reserves of active forms of humus in the $0-20 \mathrm{~cm}$ soil layer reached $58-60 \%$ of the total reserves in the $0-40 \mathrm{~cm}$ layer, whereas under ploughing - 40-44 \%, and under subsurface tillage at different depth $-52-53 \%$. The redistribution of active forms of humus in the humus horizon of chernozem was remarkable for all the variants of chernozem tillage, and the variants differed in the degree of differentiation manifestation within the humus horizon. The restoration of differentiation by the content of active humus is a natural process of soil formation in agroecosystems and it should be stimulated by the soil-protective system of tillage instead of being ruined by ploughing.

The change in the ratio of humus components in chernozem under the impact of soil-protective systems of tillage is related to the increase in the reserves of total humus in the humus horizon of chernozem. Under systematic ploughing, with the introduction of a sufficient amount of mineral and organic fertilizers, the reserves of humus were smaller compared to the variants, where the subsurface tillage was conducted. Taking into account the fact that in all the variants PHS were in the same amount, the increase in the reserves of total humus took place due to the accumulation of detritus, and the ratio of PHS reserves and the detritus reserves under surface tillage was smaller (1.831.91 to 1$)$, whereas under subsurface tillage at diffe- 


\section{DEMYDENKO et al.}

rent depth and ploughing the ratio was getting broader. While keeping the fallow, the ratio of the reserves of PHS and the reserves of detritus was stable at the level of $1.65-1.75$ to 1 .

The systematic implementation of soil-protective technologies in the crop rotation, based on subsurface tillage and covering the surface with manure, afterharvest and root remains, somehow restores the chernozem process of soil formation, which is manifested in the accumulation of detritus, active (newly formed) forms of humus in the organic matter and in the increase of total reserves of humus. The intensive cultivation (tillage) of chernozem promoted the increase in the content of active forms of humus due to biological transformation of some passive humus into its active form: humus got renewed due to the mineralization of PHS, which was related to the decrease in its content and reserves in the centennial cycle. The application of the soil protective tillage of chernozem for 42 years resulted only in the delay in dehumification processes and some stabilization of humus mineralization, but it did not promote its preservation and extended restoration to the initial level as of the moment of starting the experiment and in the centennial cycle. The increase in the humus content took place compared to ploughing and control variant without fertilizers and with their introduction, but it is not enough for the restoration of humus in the centennial cycle. The application of soil restoring measures (subsurface tillage, fertilizers, manure, straw, grasses) should be viewed as stabilizing measures in the centennial process of chernozem dehumification.

\section{CONCLUSIONS}

The estimation of the humus state of typical low humus chernozem was used to determine that under different systems of tillage the level of humus supply changes the most in the first years after the beginning of the mentioned actions, then the humus content stabilizes and changes very slowly time-wise due to the transition of humus formation processes into the quasiequilibrium state with degradation phenomena.

The application of different technologies of tillage to typical low humus chernozem for 42 years resulted only in the delay in dehumification processes and some stabilization of humus mineralization, but it did not promote its preservation and extended restoration to the initial level as of the moment of starting the experiment. The increase in the humus content under different technologies of tillage took place compared to ploughing and the control variant without any fertilizers.
To ensure simple and extended restoration of humus in the centennial cycle, it is necessary to introduce 10-12 t of manure per 1 ha for simple restoration of total humus content and 14-15 t per $1 \mathrm{ha}$ - for extended restoration annually. In case of replacing manure with by-products, the standardized dose of manure (coefficient 3.5) by the yield of straw is 10-12 t per 1 ha and $14-16$ t per 1 ha annually, which is actually impossible in industrial conditions.

Simple restoration of humus in typical chernozem may be stated after achieving its actual (2017) content of at least $90 \%$ from the content as of the beginning of the centennial cycle ( 92 years), which ensures maximal approximation to the non-decreasing cycle of humus dynamics trends in the centennial cycle. If the humus content is ensured in the actual measurement for the level, exceeding $90 \%$ from the initial content, and dynamics trends are growing, one may state achieving the state of extended restoration of humus.

\section{Багаторічна динаміка вмісту гумусу за різних технологій обробітку грунту}

О. В. Демиденко ${ }^{1}$, П. І. Бойко ${ }^{2}$, В. А. Величко ${ }^{3}$

1 Черкаська державна сільськогосподарська дослідна станція ННЦ «Інститут землеробства», Вул. Докучаєва, 13, сел. Холоднянське,

Смілянський р-н, Черкаська обл., Україна, 20731; e-mail: smilachiapv@ukr.net

${ }^{2}$ ННЦ «Інститут землеробства НААН», Вул. Машинобудівників, 2-б, смт Чабани, Києво-Святошинський р-н, Київська обл. e-mailiznaan@ukr.net

${ }^{3}$ ННЦ «Інститут грунтознавства та агрохімії імені О.Н. Соколовського», Харків, Вул.Чайковського,4, Харків, Україна,61024; e-mail: agrovisnyk@ukr.net

У тривалому стаціонарному досліді виявлено багаторічну динаміку вмісту загального гумусу і дано прогноз зміни вмісту гумусу в чорноземі типовому малогумусному за різних способів обробітку до 2050 року. Мета. Визначити темпи динаміки накопичення гумусу і мінералізації загального гумусу та розробити прогноз зміни його вмісту в довгостроковому стаціонарному польовому досліді за тривалого застосування різних способів обробітку грунту чорнозему типового малогумусного лівобережного Лісостепу України. Методи. Польовий, лабораторно-аналітичний, математичний та статистичний. Результати. Застосування різних способів обробітку чорнозему типового малогумусного впродовж 42 років призвело лише до затримки процесів дегуміфікації і в певній мірі стабілізу- 


\section{LONG-TERM DYNAMICS OF HUMUS CONTENT UNDER DIFFERENT TECHNOLOGIES OF SOIL TILLAGE}

вало мінералізацію гумусу, але не сприяло його збереженню та розширеному відтворенню до початкового рівня на момент закладки досліду. Зростання вмісту загального гумусу для простого і розширеного відтворення гумусу у віковому циклі рівноцінне: 20-25 т та 30-33 т на 1га відповідно. Для забезпечення зростання вмісту і запасу гумусу на протязі 42 років необхідно щорічно вносити гною 10-12 т на 1 га для простого і 14-15 т на 1 га розширеного відтворення загального вмісту гумусу щорічно Висновки. Просте відтворення гумусу чорнозему типового можна констатувати при досягненні його реального (2017 р.) умісту не менше 90 \% від умісту з початку відліку вікового циклу (92 роки), що забезпечує максимальне наближення до неспадного циклу трендів динаміки гумусу у віковому циклі. Якщо уміст гумусу забезпечується у реальному вимірі на рівні більшому за 90 \% від початкового вмісту, а тренди динаміки набувають зростаючого характеру, то можна констатувати досягнення стану розширеного відтворення гумусу. Досягнення стану простого i розширеного накопичення гумусу забезпечується додатністю трендів зростання гумусу за час проведення стаціонарного досліду (42 роки) при одночасному зниженні процесу дегуміфікації у віковому циклі (92 роки), яке повністю знівелювати неможливо.

Ключові слова: чорнозем типовий, органічна речовина, гумус, тренд, солома, гній, мінеральні добрива, гуміфікація, обробіток грунту.

\section{Многолетняя динамика содержания гумуса при различных технологиях обработки почвы}

А. В. Демиденко ${ }^{1}$, П. И.Бойко ${ }^{2}$, В. А.Величко ${ }^{3}$

1 Черкасская государственная сельскохозяйственная опытная станция

Ул. Докучаєва, 13, с. Холоднянское, Смелянского р-он,

Черкасской обл., Украина, 20731; e-mail: smilachiapv@ukr.net

${ }^{2}$ ННЦ «Институт земледелия НААН»

Ул. Машиностроителей, 2-б, пгт Чабаны, Киево-

Святошинский р-н, Киевская обл. e-mail: iznaan@ukr.net

${ }^{3}$ ННЦ «Институт почвоведения и агрохимии имени А.Н. Соколовского»,ул.Чайковского, 4, Харьков, Украина,61024; e-mail: agrovisnyk@ukr.net

Цель. Определить темпы динамики накопления и минерализации общего гумуса и разработать прогноз изменения его содержания в долгосрочном стационарном полевом опыте при длительном применении различных способов обработки чернозема типичного мало-гумусного левобережной Лесостепи Украины. Методы. Полевой, лабораторно-аналитический, математический и статистический. Результаты. Примене- ние различных способов обработки чернозема типичного малогумусного в течение 42 лет привело лишь к задержке процессов дегумификация и в определенной степени стабилизировало минерализацию гумуса, но не способствовало его сохранению и расширенному воспроизводству к исходному уровню на момент закладки опыта. Рост содержания общего гумуса для простого и расширенного воспроизводства гумуса в вековом цикле равноценны 20-25 т и 30-33 т на 1 га соответственно. Для обеспечения установленных прибавок гумуса необходимо ежегодно вносить навоза 10-12 т на 1 га для простого и 14-15 т на 1 га расширенного воспроизводства общего содержания гумуса ежегодно Выводы. Простое воспроизводство гумуса чернозема типичного можно определить, как достижение его реального (2017 г.) содержимого не менее $90 \%$ от содержимого начала отсчета векового цикла (92 года), что обеспечивает максимальное приближение к возрастающему тренду динамики гумуса в возрастном цикле. Если содержание гумуса обеспечивается в реальном измерении на уровне, превышающем 90 \% от первоначального содержания, а тренды динамики приобретают возрастающий характер, то можно констатировать достижение состояния расширенного воспроизводства гумуса. Достижение состояния простого и расширенного накопления гумуса обеспечивается положительностью трендов роста гумуса за время проведения стационарного опыта (42 года) при одновременном снижении процесса дегумификации в возрастном цикле (92 года), которую полностью нивелировать невозможно.

Ключевые слова: чернозем типичный, органическое вещество, гумус, тренд, солома, гной, минеральные удобрения, гумификация, обработка почвы.

\section{REFERENCES}

1. Alexandrova L.N. Organic matter of soil and the processes of its transformation. L: Nauka, 1980:288 p.

2. Kononova M.M. Organic matter and soil fertility. Pochvovedenie. 1984;(8):6-20 p.

3. Bulyhin SYu, Dehtiariov VV, Krokhin SV. Humus state of chernozems of Ukraine. Visnyk ahrarnoi nauky. 2007;(2):13-7.

4. Velychko VA, Demydenko OV, Kryvda YuI. Humus state of typical chernozems of the Left-Bank central ForestSteppe and restoration of their fertility. Visnyk ahrarnoi nauky. 2013;(7):20-4.

5. Demydenko $O V$, Shykula $M K$. Humus state of typical chernozem in the conditions of the Left-Bank ForestSteppe. Visnyk ahrarnoi nauky. 2004;(2):5-11.

6. Bationo A, Buerkert A. Soil organic carbon management for sustainable land use in Soudano-Sahelian West Africa. Nutrient cycling in Agroecosystems. 2001;61:131-42.

7. Bertolini P, Tian SP. Low-temperature biology and pa- 


\section{DEMYDENKO et al.}

thogenicity of Penicillium hirsulum on storage. Postharvest Biology and Technology. 1996;7(1-2):83-9.

8. Buckley DH, Schmidt TM. The structure of microbial communities in soil and the lasting impact of cultivation. Microb. Ecol. 2001;42(1):11-21.

9. Campbell CA, Lafond GP, Zentner RP, Biederberck VO. Influence of fertilizer on soil organic matter in a thin black chernozem in western Canada. Soil Biol. Biochem. 1991;23(5):443-6.

10. Balesdent J, Wagner GH, Mariotti A. Soil organic matter turnover in long-term field experiments as revealed by carbon - 13 natural abundance. Soil Sci. Am. J. 1988;52(1):118-24.

11. Pantera H, Zurawski $H$. The influence of fertilization with straw on the number of micro-organisms of selected groups and on some chemical properties of light soil. Budapest: Inst. Soil Sci. 1987;1:513-20.

12. Szegi J. et al. Effect of fertilization and organic matter application on soil respiration dynamics. Proc. 9th Int. Symp. Soil Biol. Consery. Biosphere Sopron, 27-30 Aug. 1985. Budapest, 1987;2:743-54.

13. Dehtiariov VV, Syniavin VD, Kolupayeva YeM. Specificities of humus accumulation in typical chernozem of the Left-Bank Forest-Steppe of Ukraine depending on the duration and character of their agricultural application. Materials of scient. conf.of Kharkiv State Agrarian Univ. Kharkiv. 1995:22-4.

14. Diakonova $K V$, Kohut BM. The system of indices of humus state for fertility models of chernozems. Fertility of chernozems due to intensification of their use. Scient. works of Dokuchaev V.V. Soil Research Institute. M. 1990:211-7.

15. National report on the state of soil fertility of Ukraine. K.: VIK-PRINT LLC, 2010:111 p.

16. Tiurin $I V$. Organic matter of soil and its role in fertility. M.: Nauka, 1965:320 p.
17. Sorokyna NP, Kohut BM. Dynamics of humus content in arable chernozem and approaches to its study. Pochvovedenie. 1997;(2):178-84.

18. Yakushev VP, Bure VM, Yakushev VV. Creating and analyzing empirical dependences. StPb: Publishing house of Saint Petersburg University, 2005:38 p.

19. Gromovik AI. Long-term dynamics of humus content in leached chernozem in conditions of continuous application of fertilizers. Vestnik VGU. Ser.: Chemistry. Biology. Pharmacia. 2012;(1):71-6.

20. Zinovieva $K h G$. Short report of the agrotechnical laboratory of field research division for 1925-1927. Edited by Levitsky N.O. Zolotonosha. 1928:55 p.

21. Moiseev KG. Application of similarity methods to the physical experiment. Physical, chemical and climatic factors of field productivity. StPb: Publishing house of PIYaF RAN. 2007:72-77.

22. Moiseev KG, Boitsova LV, Goncharov VD. Analyses of soil humus dynamics by fractal methods. Agrophysics. 2014;1(13):1-8.

23. Globus AM. Fractality of some physical properties of soil. Physical, chemical and climatic factors of field productivity. StPb: Publishing house of PIYaF RAN. 2007:16-21.

24. Rieu M, Sposito G. Fractal fragmentation, soil porosity, and soil water property: I. Theory. Soil Sci. Soc. Am. J. 1991;55:1231-8.

25. Laktionov NI, Dehtiariov VV, Karpenko IV. The role of detritus in structure formation. Soil cover of Ukraine and its rational use: scient. conf., dedicated to 175-anniversary of KhGAU: theses of reports. Kharkiv. 1992:31-2.

26. Dehtiariov VV. Humus of chernozems in the Left-Bank Forest-Steppe and Steppe of Ukraine. Kh.: Maydan. 2011:360 p. 